\title{
Мож.ливості радикального лікування папілярних карцином щитоподібної залози методом мініінвазивної хірургії
}

\begin{abstract}
Мета роботи: розробити та ретроспективно оцінити результати хірургічного методу міні-доступу до щитоподібної залози у хворих з диференційованим тиреоїдним раком.

Матеріали і методи. Проаналізовано результати обстеження та хірургічного лікування 60 хворих із папілярними карциномами щитоподібної залози, прооперованих із застосуванням мініінвазивного методу, який полягає в зменшенні хірургічного розрізу до 2,5-3 см на рівні нижнього краю перешийка щитоподібної залози. Оцінювання результатів удосконаленого методу проводили за такими критеріями: кількість днів перебування у стаціонарі, частота ускладнень (однобічне транзиторне пошкодження зворотного гортанного нерва, транзиторна гіпокальціємія, кровотеча), стан післяопераційних рубців.

Результати досліджень та їх обговорення. Запропонований спосіб міні-доступу при хірургічному втручанні на щитоподібній залозі за її пухлинної патології є менш травматичним, більш радикальним та абластичним порівняно з традиційним. Частота післяопераційних ускладень не відрізнялася від такої при операціях із використанням звичайного доступу, водночас у жодному випадку не спостерігали у післяопераційному періоді випадків кровотечі. При оцінюванні стану післяопераційних рубців встановлено, що у всіх хворих кількість балів, які були нараховані за Stony Brook, була не нижче 3. Зменшення довжини розтину має позитивний не тільки косметичний, а й психологічний ефекти, комфортний для пацієнтів, створює умови для кращої реабілітації пацієнтів усіх вікових категорій.
\end{abstract}

Ключові слова: диференційований рак щитоподібної залози; тиреоїдектомія; міні-доступ.

Постановка проблеми та аналіз останніх досліджень та публікацій. Вимоги до сучасної хірургії полягають не тільки в адекватності та радикальності хірургічного втручання, але і в тому, щоб мінімізувати наслідки оперативного лікування та прискорити процес одужання та реабілітації пацієнтів. Традиційні доступи до щитоподібної залози (ЩЗ) за Кохером полягають у виконанні розтину шкіри завдовжки 5-6-8 см. Ендоскопічні методики видалення щитоподібної залози у випадках раку щитоподібної залози, на сучасному етапі, ще не мають широкого впровадження, тривалі за часом та дороговартісні. Проте пошук найоптимальніших методик хірургічного лікування захворювань ЩЗ триває.

Останніми роками в хірургії ЩЗ значного поширення набули мініінвазивні втручання, зокрема з використанням відеоендоскопічних і роботизованих технологій. Передумови до їх застосування зумовлені збільшенням числа хворих із хірургічною патологією ЩЗ, удосконаленням діагностичних можливостей та раннім виявленням злоякісних новоутворень, розвитком ендовідеохірургічних технологій і відпрацюванням критеріїв вибору мініінвазивних втручань, прагненням поліпшити якість життя хворих, прискорити їх трудову і соціальну реабілітацію [1, 2].

Загальновідомими малоінвазійними доступами до ЩЗ є міні-доступи на передній поверхні шиї, пахвові, передні грудні, параареолярні та ін. Най- більше визнання і поширення в клінічній практиці набули втручання з серединного шийного доступу та ендоскопічні, що поєднують переваги пахвових доступів і параареолярних. Водночас загальновизнаних і затверджених протоколів щодо застосування таких втручань, як і раніше, немає, показання та протипоказання залишаються предметом дискусії і базуються на досвіді окремих авторів. Отже, поява великого набору мініінвазивних технологій визначила проблеми, які пов'язані з вибором оптимального доступу для втручань на ЩЗ залежно від клінічної та морфологічної форми захворювання.

При порівнянні результатів різних доступів з'ясовано, що протипоказами до застосування відеоасистованих та ендоскопічних операцій є високодиференційовані карциноми розміром понад 20 мм, наявність регіонарних метастазів, автоімунний тиреоїдит, токсичні форми зоба, попередні операції та променева терапія в ділянці шиї. При наявності цих протипоказань оперативне втручання доцільно виконувати за методикою мініінвазивного доступу [3], за якою можна проводити екстрафасціальну тиреоїдектомію, дисекцію лімфовузлів центрального відсіку та ревізію інших груп колекторів лімфатичного відтоку. Отже, на відміну від вартісних відеоендоскопічниих методик розробка методів мініінвазивних оперативних втручань у випадках диференційованого раку ЩЗ, які не будуть поступатися за косметичним ефектом, але будуть доступними 
більшості хірургів та пацієнтів, є нагальною проблемою сучасної онкоендокринології.

Мета роботи: розробити та ретроспективно оцінити результати хірургічного методу міні-доступу до ЩЗ у хворих з диференційованим тиреоїдним раком.

Матеріали і методи. Проаналізовано результати обстеження та хірургічного лікування 60 хворих з папілярними карциномами ЩЗ, прооперованих із застосуванням мініінвазивного методу. Обстеження хворих здійснювали відповідно до існуючих клінічних рекомендацій, а критерії відбору пацієнтів відповідали загальноприйнятим і враховували основні чинники: розмір пухлинних утворень, об’єм ЩЗ, наявність екстратиреоїдного поширення та ураження регіонарних лімфатичних вузлів $[1,4]$. Вік пацієнтів коливався від 16 до 62 років. Розміри пухлини становили від 0,5 до 3,5 см.

Оцінювання результатів удосконаленого методу проводили за такими критеріями: кількість днів перебування у стаціонарі, частота ускладнень (пошкодження зворотного гортанного нерва, транзиторна гіпокальціємія, кровотеча), стан післяопераційних рубців. Останнє проводили за бальною шкалою оцінки рубців Stony Brook Scar Evaluation Scale (SBSES) через 1-2 місяці після операції (кількість хворих - 47). Шкала включає оцінку ряду параметрів за подвійною системою (0 чи 1 бал), загальна оцінка складає від 0 (найгірший вид) до 5 (відмінний вид).

Результати досліджень та їх обговорення. Протокол виконання способу хірургічної операції, що пропонуєтся, передбачає: 1) за 30-40 хв парентарально призначають антибіотик широкого спектра дії у добовій дозі для профілактики інфекційних ускладнень та набряку тканин у ранньому післяопераційному періоді та нестероїдний протизапальний препарат для зменшення больового

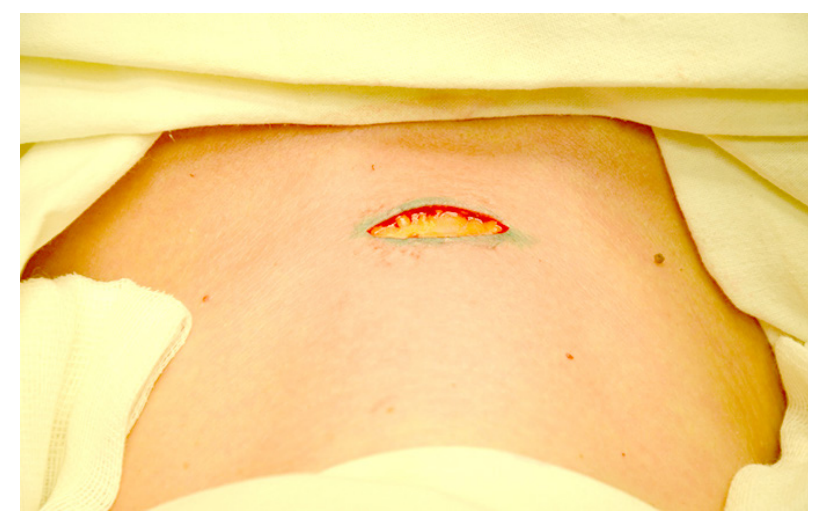

Фото 1. Маркування операційного розтину. синдрому, а також набряку в ранньому післяопераційному періоді; 2) безпосередньо на операційному столі (фото 1) проводять маркування розтину брильянтовим зеленим (Viride nitens) завдовжки 2,5-3 см на рівні нижнього краю перешийка ЩЗ і проводять розтин шкіри до платизми. Останню перетинають за допомогою діатермічної електроексцизії. Наступні оперативні маніпуляції проводять при використанні апарата високочастотного зварювання живих тканин (“ПатонМед”), перевагами використання якого є малотравматичність, надійність гемостазу, відсутність некрозу тканин, висока абластичність, скорочення тривалості оперативних втручань; 3) претиреоїдні м'язи роз'єднуюють по серединній лінії та розводять по боках (фото 2). Додатково для покращення доступу та мобілізації часток проводять невеликий (до 1 см) розтин груднино-щитоподібного м'яза в поперечному напрямку; 4) виконують ревізію обох часток залози. На першому етапі видаляють пірамідальну частку ЩЗ, далі перетинають перешийок. Першою видаляють частку з пухлиною, потім - контрлатеральну частку залози. При видаленні як правої, так і лівої часток технічні моменти та прийоми майже однакові. Видалення розпочинають з мобілізації медіального краю частки ЩЗ (від трахеї), після чого частку (для збільшення огляду та полегшення мобілізації) затискають щипцями типу Мюзо чи Аліса (фото 3) для проведення періодичної та помірної тракції; 5) поетапна мобілізація нижнього полюсу залози до візуалізації та сепарації нижньої прищитоподібної залози (фото 4). Після цього проводять також поетапну мобілізацію верхнього полюсу з перев’язкою верхньої щитоподібної артерії та іїі гілок і візуалізацію та сепарацію верхньої прищитоподібної залози; 6) частку зміщують медіально та проводять мобілізацію її латерального краю з обов’язковою візуалізацією та виділенням зворотного гортанного нерва аж до входу останнього в гортань; 7) зворотний гортанний нерв обе-

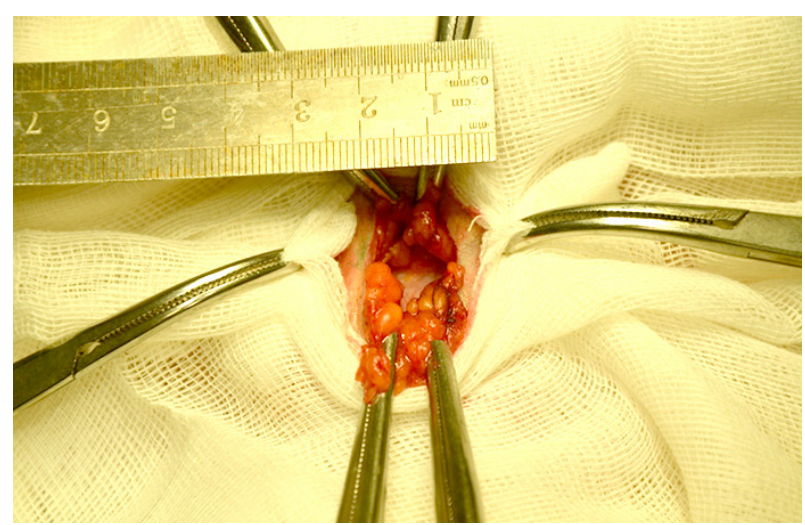

Фото 2. Роз’єднання претиреоїдних м’язів. 


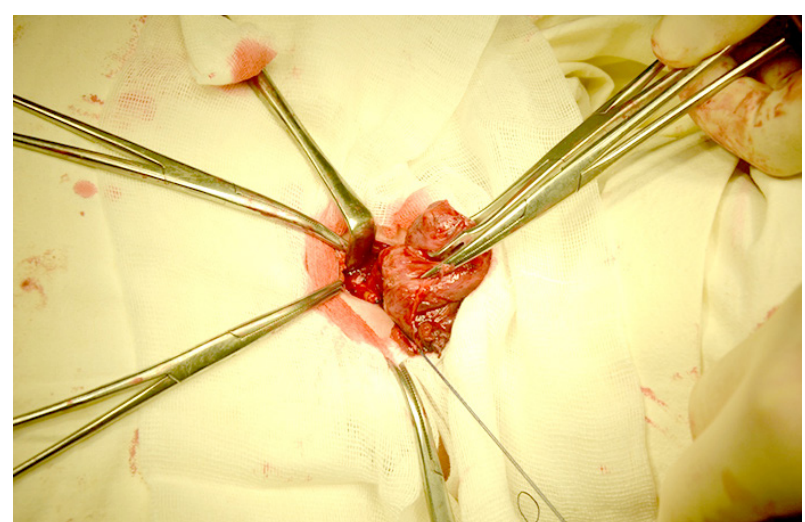

Фото 3. Проведення періодичної та помірної тракції.

режно тупим шляхом опускають та відділяють від частки ЩЗ. Всі подальші маніпуляції проводять під постійним контролем зворотного гортанного нерва (фото 5); 8) зв’язку Бері пересікають в останню чергу перед видаленням частки ЩЗ (фото 6); 9) проводять ревізію регіонарних колекторів лімфовідтоку VI відсіку (фото 7) та виконують серединну дисекцію шиї; 10) після дренування рани вакуум-аспіратором, останню пошарово ушивають вузловими швами за допомогою ниток, що роз-

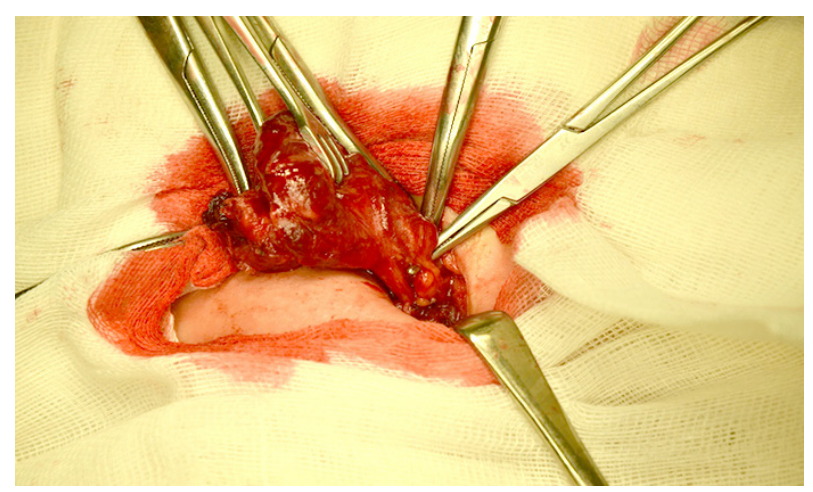

Фото 5. Мобілізація латерального краю частки залози та ідентифікація зворотного гортанного нерва.

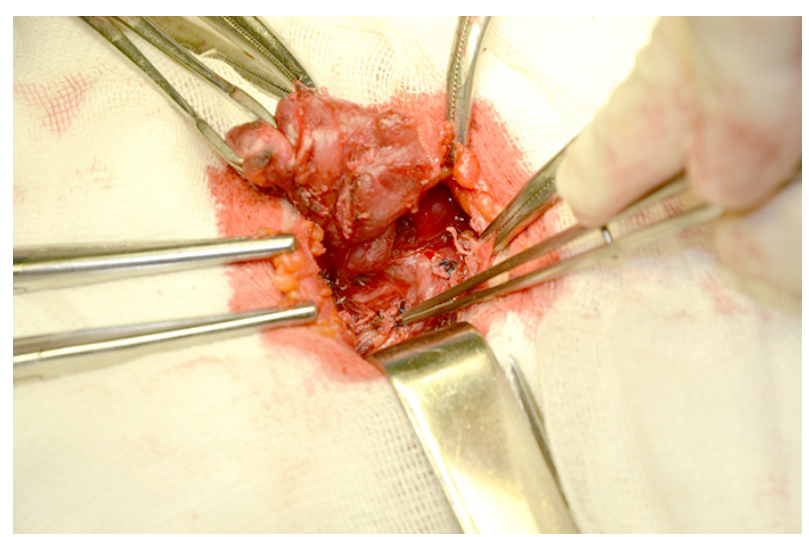

Фото. 6. Перетинання зв’язки Бері.

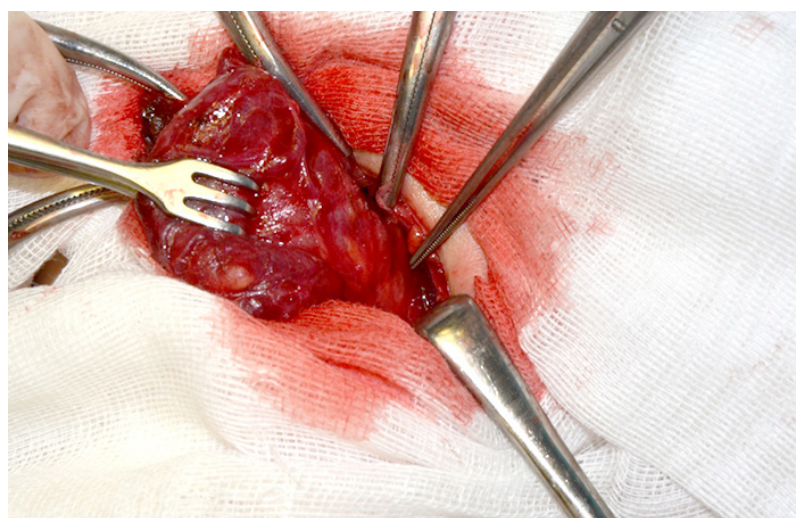

Фото 4. Поетапна мобілізація нижнього полюсу залози.

смоктуються. На шкіру накладають внутрішньошкірний косметичний шов (фото 8).

Спосіб був застосований при хірургічному лікуванні пацієнтів з папілярними карциномами ЩЗ категорії рT1-2NxMx. Тривалість операцій становила приблизно 70 хв. Дренаж видаляли за 1820 год, косметичний шов знімали на другу добу. Набряк післяопераційної рани був мінімальний, пацієнтів, як правило, виписували на другу добу після оперативного втручання.

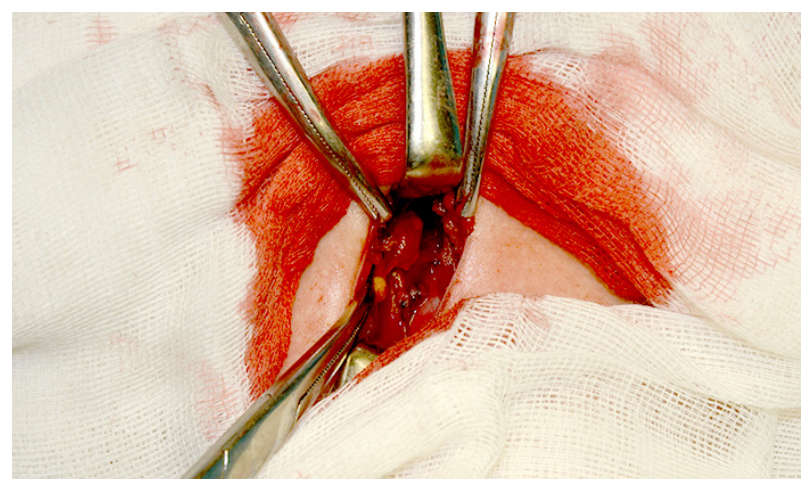

Фото 7. Ревізія регіонарних колекторів лімфовідтоку VI відсіку.

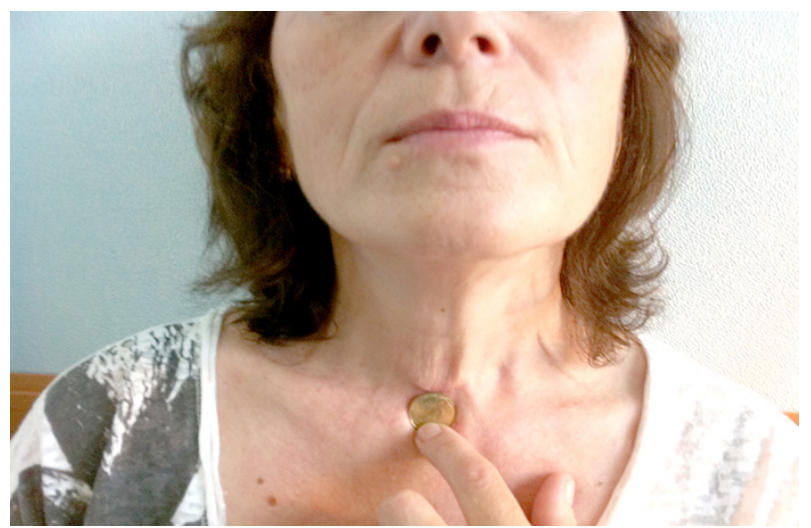

Фото 8. Косметичний результат оперативного втручання. 
У зв'язку з анатомічним розташуванням ЩЗ виконання тиреоїдектомії може призводити до таких ускладнень, як тимчасова чи постійна втрата голосу, гіпокальціємія, кровотеча тощо. Застосування мініінвазійного доступу до ЩЗ із пухлиною може зменшити частоту ускладнень [5]. За нашими даними, частота післяопераційних ускладень не відрізнялася від такої при операціях з використанням звичайного доступу (табл.). Так, якщо частота виникнення кровотечі після тиреоїдектомії, яку виконують за стандартним протоколом, становить 0,49 \% в Хірургічній клініці Інституту [6], 0,12 \% при відеоасистованих втручаннях і до 4,8 \% - при ендоскопічних [3, 7, 8], то при застосуванні мініінвазійного доступу за описаним протоколом у жодному випадку у після- операційному періоді ми не мали випадків кровотечі.

Одностороннє пошкодження зворотного гортанного нерва виникло в однієї хворої та мало транзиторний характер з повним відновленням фонації за 3 місяці. У 5 пацієнтів транзиторна гіпокальціємія тривала до 2 місяців. За даними гістологічного дослідження у 15 хворих у центральному колекторі виявлено метастази папілярного раку (див. табл.), а у 3-х (5 \%) ще й в югулярних колекторах лімфовідтоку. Всі пацієнти пройшли радіойодне лікування, УЗД-контроль, а також визначення рівня онкомаркерів у крові у термін від 1 до 3 місяців після оперативного втручання. Рецидиву захворювання не виявлено. Післяопераційний термін спостереження становив від 1 до 5 років.

Таблиця. Результати застосування мініінвазійного хірургічного втручання

\begin{tabular}{|c|c|c|}
\hline Показник & $\begin{array}{c}\text { За традиційним } \\
\text { протоколом }\end{array}$ & $\begin{array}{c}\text { За мініінвазивним } \\
\text { доступом }\end{array}$ \\
\hline Кількість пацієнтів & 65 & 60 \\
\hline Вік хворих (роки) & $18-64$ & $16-62$ \\
\hline Розмір первинної пухлини (см) & $0,5-4,0$ & $0,5-3,5$ \\
\hline Довжина розтину (см) & $4,5-8,0$ & $2,5-3,0$ \\
\hline Тривалість операції (хв) & $60 \pm 15$ & $75 \pm 15$ \\
\hline Час перебування в стаціонарі (дні) & $3 \pm 1$ & $<3 \pm 1$ \\
\hline $\begin{array}{l}\text { Частота однобічного транзиторного пошкодження зворотного } \\
\text { гортанного нерва }\end{array}$ & $1(1,5 \%)$ & $1(1,7 \%)$ \\
\hline Частота транзиторної гіпокальціємії & $6(9,2 \%)$ & $5(8,3 \%)$ \\
\hline Частота кровотечі & $1(1,5 \%)$ & $0(0,0 \%)$ \\
\hline Частота метастазів у центральному колекторі & $14(21, \%)$ & $15(25,0 \%)$ \\
\hline
\end{tabular}

При оцінюванні стану післяопераційних рубців за Stony Brook встановлено, що у 5 хворих (10,6 \%) вони були оцінені на 5 балів (тобто рубець мав відмінний вигляд), 32 пацієнта (68 \%) - на 4 бали, 10 осіб (21,4\%) - на 3 бали. Жоден з 47 пацієнтів не отримав менш ніж 3 бали (негативний результат).

Використання мініінвазивного доступу у випадках диференційованих карцином ЩЗ - радикальний та безпечний метод хірургічного втручання. Зменшення довжини розтину має позитивний не тільки косметичний (фото 8), а й психологічний ефекти, $є$ комфортним для пацієнтів чоловічої та жіночої статті, створює умови для кращої реабілітації пацієнтів усіх вікових категорій.
Висновки. 1. Запропонований спосіб мінідоступу при хірургічному втручанні на ЩЗ за її вузлової патології є менш травматичним, більш радикальним та абластичним порівняно 3 традиційним, і рекомендується для впровадження у спеціалізованих відділеннях та клініках ендокринного профілю.

2. Забезпечення методичності і безпеки виконання технічних прийомів сприяє зменшенню частоти розвитку специфічних ускладнень і терміну перебування прооперованих в стаціонарі, поліпшенню косметичних результатів і якості життя хворих.

\section{СПИСОК ЛІТЕРАТУРИ}

1. Duke W. Alternative approaches to the thyroid gland / W. Duke, D. Terris // Endocrinol. Metab. Clin. North Am. - 2014. - Vol. 43, No. 2. - P. 459-474.
2. Minimal-access video-assisted thyroidectomy for benign disease: a retrospective analysis of risk factors for postoperative complications / F. Billmann, T. Bokor-Bilmann, H. Lapshyn 
[et al.] // Int. J. Surg. - 2014. - Vol. 12. - P. 1306-1309.

3. Минимально-инвазивная хирургия щитовидной железы / Н. А. Майстренко, П. Н. Ромащенко, Д. С. Криволапов [и др.] // Международный научно-исследовательский журнал. - 2017. - № 1 (55), Ч 1. - С. 144-151.

4. Minimally invasive video-assisted thyroidectomy: reflections after more than 2400 cases performed / P. Miccoli, M. Biricotti, V. Matteucci [et al.] // Surg. Endosc. - 2016. - Vol. 30, No. 6. P. 2489-2495.

5. Разумовский А. Ю. Минимально-инвазивная хирургия щитовидной железы / А. Ю. Разумовский, 3. Б. Митупов,
Т. Е. Юшина // Детская хирургия. - 2014. - № 6. - С. 41-45. 6. Postoperative hemorrhages in thyroidal surgery / Y. Tarashchenko, A. Kovalenko, M. Bolgov [et al.] // Клиническая хирургия. - 2018. - Vol. 85, No. 9. - Р. 39-41.

7. Anuwong A. Transoral endoscopic thyroidectomy vestibular approach: A series of the first 60 human cases / A. Anuwong // World J. Surg. - 2016. - Vol. 40, No. 3. - P. 491-497.

8. Surgical complications after robotic thyroidectomy for thyroid carcinoma: a single center experience with 3,000 patients / E. Ban, J. Yoo, W. Kim [et al.] // Surg. Endosc. - 2014. - Vol. 28, No. 9. - P. 2555-2563.

\section{REFERENCES}

1. Duke, W., \& Terris, D. (2014). Alternative approaches to the thyroid gland. Endocrinology \& Metabolism Clinics of North America, 43, 2, 459-474.

2. Billmann, F., Bokor-Billmann, T., Lapshyn, H., Burnett, C., Hopt, U., \& Kiffner. E. (2014). Minimal-access video-assisted thyroidectomy for benign disease: a retrospective analysis of risk factors for postoperative complications. International Journal of Surgery, 12, 1306-1309.

3. Maystrenko, N.A., Romashchenko, P.N., Kryvolapov, D.S., Pryshvyn, A.P., \& Mykhalchenko, G.V. (2017). Minimalnoinvazivnaya khirurhgiya shchytovidnoy zhelezy [Minimal invasive thyroid gland surgery]. Mezhdunarodnyy nauchnoissledovatelskyy zhurnal - International Research Journal, 1 (55), 144-151 [in Russian].

4. Miccoli, P., Biricotti, M., Matteucci, V, Ambrosini, C., Wu, J., \& Materazzi, G.. (2016). Minimally invasive video-assisted

thyroidectomy: reflections after more than 2400 cases performed. Surgical Endoscopy, 30, 6, 2489-2495.

5. Razumovskyy, A.Yu,. Mytupov, Z.B., \& Yushyna, T.E. (2014). Minimalno-invazivnaya khirurhgiya shchytovidnoy zhelezy [Minimal invasive thyroid gland surgery]. Detskaya khyrurhyia - Children's Surgery, 6, 41-45 [in Russian].

6. Tarashchenko, Y., Kovalenko, A., Bolgov, M., Guda, B., Ostafiychuk, M., \& Kolluh, O. (2018). Postoperative hemorrhages in thyroidal surgery. Klinicheskaya Khirurgiya-Clinical Surgery, 85, 9, 39-41.

7. Anuwong, A. Transoral endoscopic thyroidectomy vestibular approach: A series of the first 60 human cases. (2016). World Journal of Surgery, 40, 3, 491-497.

8. Ban, E., Yoo, J., Kim, W., Son, H., Park, S., Lee, S., Lee, C., et al. (2014). Surgical complications after robotic thyroidectomy for thyroid carcinoma: a single center experience with 3,000 patients. Surgical Endoscopy, 28, 9, 2555-2563.

Отримано 02.05.2019

B. B. GUDA, A. E. KOVALENKO, YU. M. TARASCHENKO

V. Komisarenko Institute of Endocrinology and Metabolism of the National Academy of Medical Sciences of Ukraine

\section{POSSIBILITIES OF RADICAL TREATMENT OF THYROID PAPILLARY CARCINOMA BY MINIMAL INVASIVE SURGERY}

The aim of the work: to develop and retrospectively evaluate the results of the surgical method of access to the thyroid gland in patients with differentiated thyroid cancer.

Materials and Methods. The results of the examination and surgical treatment of 60 patients with papillary carcinoma, operated with the use of the minimally invasive method, which consists of reducing the surgical incision to $2.5-3 \mathrm{~cm}$ at the level of the lower edge of the thyroid gland, is analyzed. The evaluation of the results of the advanced method was carried out according to the following criteria: the number of days in hospital, the frequency of complications (one-sided transient damage to the laryngeal nerve, transient hypocalcemia, bleeding), postoperative scar condition.

Research and Discussion. The proposed method of mini access for surgical intervention on the thyroid gland due to its nodal pathology is less traumatic, more radical and ablastic compared with the traditional one. The frequency of postoperative complications did not differ from that in operations using conventional access, while in no case were observed in the postoperative period of cases of bleeding. In assessing the state of postoperative scarring, it was found that in all patients the number of points scored for Stony Brook was not lower than 3 . The decrease in the length of the opening has a positive not only cosmetic but also psychological effects, is comfortable for patients, creates conditions for better rehabilitation patients of all ages.

Key words: differentiated thyroid cancer; thyroidectomy; minimally invasive thyroidectomy. 


\section{Б. Б. ГУДА, А. Е. КОВАЛЕНКО, Ю. М. ТАРАЩЕНКО}

ГУ “Институт эндокринологии и обмена веществ имени В. П. Комиссаренко НАМН Украины”

\section{ВОЗМОЖНОСТИ РАДИКАЛЬНОГО ЛЕЧЕНИЯ ПАПИЛЯРНЫХ КАРЦИНОМ ШИТОВИДНОЙ ЖЕЛЕЗЫ МЕТОДОМ МИНИИНВАЗИВНОЙ ХИРУРГИИ}

Цель работы: разработать и ретроспективно оценить результаты хирургического метода мини-доступа к щитовидной железе у больных с дифференцированным тиреоидными раком.

Материалы и методы. Проанализированы результаты обследования и хирургического лечения 60 больных с папилярными карциномами щитовидной железы, прооперированных с применением миниинвазивного метода, который заключается в уменьшении хирургического разреза до 2,5-3 см на уровне нижнего края перешейка щитовидной железы. Оценку результатов усовершенствованного метода проводили по следующим критериям: количество дней пребывания в стационаре, частота осложнений (одностороннее преходящее повреждения возвратного гортанного нерва, транзиторная гипокальциемия, кровотечение), состояние послеоперационных рубцов.

Результаты исследований и их обсуждение. Предложенный способ мини-доступа при хирургическом вмешательстве на щитовидной железе при ее узловой патологии является менее травматичным, более радикальным и абластичным по сравнению с традиционным. Частота послеоперационных осложнений не отличалась от таковой при операциях с использованием обычного доступа, однако не наблюдали в послеоперационном периоде случаев кровотечения. При оценке состояния послеоперационных рубцов установлено, что у всех больных количество баллов, которые были начислены по Stony Brook, было не ниже 3. Уменьшение длины разреза имеет положительный не только косметический, но и психологический эффекты, является комфортным для больных, создает условия для лучшей реабилитации пациентов всех возрастных категорий.

Ключевые слова: дифференцированный рак щитовидной железы; тиреоидэктомия; мини-доступ. 